\title{
PENGARUH PENGUNAAN BEBERAPA JENIS FILLER TERHADAP SIFAT KIMIA CHICKEN NUGGET AYAM PETELUR AFKIR
}

\author{
Sylvia Komansilan* dan Sjaloom Sakul
}

Fakultas Peternakan Universitas Sam Ratulangi Manado, 95115

\begin{abstract}
ABSTRAK
Penelitian mengenai pengaruh penggunaan beberapa jenis filler terhadap sifat kima chicken Nugget telah dilakukan. Penelitian ini bertujuan untuk mengetahui dan mempelajari jenis filler yang berbeda dalam menghasilkan formulasi chicken nugget yang diterima oleh konsumen ditinjau dari sifat kimia. Penelitian ini dilaksanakan di Laboratorium Teknologi Hasil Ternak, dan Laboratorium Nutrisi Fakultas Peternakan Universitas Sam Ratulangi Manado. Bahan penelitian ini adalah daging dan lemak ayam petelur afkir sebanyak 6400 gram yang dibagi menjadi 16 sampel dengan berat masingmasing 100 gram lemak dan daging 300 gram. Penelitian ini dilaksanakan melalui suatu percobaan dengan menggunakan Rancangan Acak Lengkap (RAL) dengan 4 ulangan. Sebagai perlakuan digunakan beberapa jenis filler yaitu; T1 (tepung Sagu), T2 (tepung tapioka), T3 (tepung maisena), T4 (tepung beras ketan). Parameter mutu chicken nugget $(\mathrm{pH}$, kadar air, kadar abu, kadar lemak, kadar protein, kadar karbohidrat). Dari hasil penelitian ini menunjukkan bahwa bahan pengisi filler dengan menggunakan tepung tapioka (T2) dan tepung sagu (T1) menghasilkan chicken nugget yang lebih baik dibandingkan dengan tepung maisena (T3), tepung beras ketan (T4).
\end{abstract}

*Korespondensi (corresponding author) Email:sylviakomansilanmdo@gmail.com
Kata Kunci: Filler, Chicken Nugget, sifat kimia.

\section{ABSTRACT}

THE INFLUENCE OF THE USE OF VARIOUS FILLERS TOWARDS THE CHEMICAL CHARACTERISTICS OF CHICKEN NUGGET. The objectives in this research is to observe and study the fillers that vary in producing the formulation of chicken nugget which were received by the consumers observed from the physical. This research was conducted at the Laboratory of Animal Science Sam Ratulangi University Manado, The Laboratory of Nutrient Faculty of Animal Science Sam Ratulangi University Manado. The material used in this research was meat and fat of non-productive layer (culled) as much as 6400 gram, devided into 16 samples, each sample weighed 100 gram fat and 300 gram meat. The research was carried out through an experient, a completely randomized design with four replications. The fillers used in this treatment were; T1 (Sago), T2 (Tapioka) T3 (Maizena), T4 (Glutten Rice). The Quality of chicken nugget according to the parameter ini this research was as follows; the chemical characteristic ( $\mathrm{pH}$, water, ash, fat, protein, and carbohydrate level). From the result of this research it was concluded that the filler which used tapioca (T2) and Sago (T1), had produced chicken nugget which was much better, compared to the use of maizena (T3), glutten rice flour (T4), and generally accepted by the consumers, supported by their characteristics. 
Keyword: Filler, Chicken Nugget, chemical characteristic

\section{PENDAHULUAN}

Produk peternakan yang cukup besar permintaannya menunjukkan kebutuhan yang cenderung meningkat setiap tahunnya berupa daging. Daging mempunyai manfaat besar bagi manusia, karena merupakan makanan yang bergizi tinggi yaitu kaya akan protein, mineral, vitamin dan lemak serta zat-zat lain yang kesemuanya sangat dibutuhkan tubuh. Disamping potensi produksi dan pasar yang tersedia, produk peternakan juga mempunyai potensi teknologi yang bisa diterapkan untuk meningkatkan nilai tambah produksi peternakan yang ada. Teknologi tersebut meliputi teknologi pananganan yang ditekankan untuk mengurangi atau menekan terjadinya kerusakan atau kehilangan produksi peternakan serta teknologi pengolahan. Pada prinsipnya bahan pangan mentah dapat dijadikan produk makanan siap dikonsumsi. Pesatnya perkembangan produk pangan seperti ini tidak lepas dari perkembangan ilmu pengetahuan tentang sifat fungsional komponen-komponen pangan yang terlihat jika komponenkomponen ini sudah berinteraksi dengan komponen-komponen lainnya dalam suatu sistim makanan dengan multi komponen.
Daging ayam petelur afkir yang sudah tua atau yang kurang produkstif mempunyai sifat lebih alot dibandingkan dengan daging ayam broiler. Upaya-upaya telah dilakukan agar daging ayam petelur afkir lebih empuk serta bertujuan untuk penganekaragaman produk hasil ternak lainnya antara lain: dendeng, abon bakso, dan lain sebaginya. Salah satu potensi yang cukup besar yakni tersedianya ayam afkir dari ayam petelur yang memiliki kualitas yang lebih rendah. Oleh karena itu diperlukan teknik pengolahan sebagai upaya peningkatan daya guna ayam petelur afkir sehingga lebih disukai oleh konsumen yang semkin menuntut variasi produk olahan dengan demikian disversifikasi dari produk ini semakin penting, dan perlu dilakukan pengembangan indnustri pengolahan hasil-hasil peternakan (Das et al., 2006).

Pengolahan daging seperti halnya pengolahan bahan lainnya bertujuan untuk memperpanang masa simpan, memperbaiki sifat organoleptik, menambah variasi bentuk olahan daging, memungkinkan tersedianya produk daging siap saji. Pengolahan daging di Indonesia sudah banyak dilakukan, baik yang diolah secara sederhana maupun dengan alat-alat modern.

Chicken nugget adalah suatu bentuk produk olahan daging ayam yang digiling, dicetak dengan menggunakan cetakan 
diberi bahan pelapis dengan atau tanpa penambahan bahan makanan lain dan bahan tambahan makanan yang diizinkan. Dalam proses pembuatan chicken nugget selain bahan cacahan daging dan bumbu sering ditambahkan bahan pengisi filler (Gumilar et al., 2011). Maksud penambahan bahan pengisi pada produk daging emulsi adalah untuk: meningkatkan stabilitas emulsi, meningkatkan daya ikat air produk daging, meningkatkan flavor, mengurangi pengerutan selama pemasakan, meningkatkan karakteristik irisan produk dan mengurangi biaya formulasi. Menurut (Ginting, 2006), tepung berpati yang biasa digunakan dalam pembuatan chicken nugget adalah tepung tapioka. Beberapa jenis tepung berpati yang berpotensi sebagai filler adalah tepung sagu, tepung maizena dan tepung beras ketan. Tepung sagu mempunyai kelebihan yaitu ukuran granula yang lebih besar serta kandungan amilosa yang tinggi, tepung maizena merupakan pati yang diekstrak dari jagung, dan mengandung kadar amilopektin yang cukup tinggi, serta tepung beras ketan yang juga mengandung kadar amiolopektin yang tinggi. Menurut Alam et al. (2008), adanya amilosa dan amilopektin dalam pati bahan pengisi menyebabkan kecenderungan menyerap air serta sifat gelatinisasi yang baik. Sifat ini ditandai oleh tidak larutnya granula pati dalam air dingin namun dapat mengembang dalam air hangat (Rohaya et al., 2013). Pilihan untuk memanfaatkan tepung berpati tersebut selain untuk memperluas kegunaannya juga tersedia dipasaran. Bahan-bahan berpati ini banyak terdapat di daerah Sulawesi Utara dan merupakan potensi yang sangat besar untuk memberdayakan produk-produk lokal yang ada tanpa pasokan dari daerah lain. Demikian selanjutnya dengan memanfaatkan tepung-tepung berpati sebagai filler akan dapat dihasilkan aneka rasa nugget.

Penelitian ini diarahkan untuk mempelajari bahan pengisi filler yang mempunyai struktur, sifat fungsional dan kadar protein, lemak abu serta karbohidrat yang beragam sehingga hal ini akan mempengaruhi sifat kimia, dari chicken nugget yang dihasilkan. Untuk itu perlu dikaji pengaruh penggunaaan beberapa jenis filler, terhadap sifat kimia chicken nugget ayam petelur afkir.

\section{MATERI DAN METODE PENELITIAN}

\section{Tempat dan Waktu Penelitian}

Penelitian ini dilaksanakan di Laboratorium Teknologi Hasil Ternak dan Laboratorium Nutrisi Fakultas Peternakan, Universitas Sam Ratulangi Manado.

\section{Materi penelitian}


Bahan-bahan untuk pembuatan chicken nugget terdiri dari daging dan lemak dari ayam petelur afkir strain Logman sekitar 24 bulan. Sebagai bahan pengisi digunakan tepung tapioca, tepung sagu, tepung maizena dan tepung beras ketan. Bumbu-bumbu (merica bubuk, penyedap, bawang putih) selain bumbu digunakan tepung panir, telur, susu bubuk serta es. Alat-alat yang digunakan yaitu, pisau, telenan food procecor, blender, plastik, dandang kukus, kompor,timbangan analitik, cetakan kue, untuk anlisa kimia digunakan cawan porselen, labu kjedal, oven, gelas ukur, botol timbang, desikator, waterbath (penangas air).

\section{Metode Penelitian}

Penelitian ini menggunakan Rancangan Acak Lengkap (RAL) yang terdiri dari 4 perlakuan dan 4 ulangan. Sebagai perlakuan adalah Chicken Nugget dengan beberapa jenis filler yaitu: $\mathrm{T} 1$ = menggunakan tepung sagu $\mathrm{T} 2=$ menggunakan tepung tapioka $\mathrm{T} 3$ = menggunakan tepung maizena T4 = menggunakan tepung beras ketan

\section{Analisis data}

Data yang diperoleh dari masingmasing parameter yang diukur dan diolah dengan menggunakan minitab. Data tersebut dianalisis dengan analisis keragaman (analiysis of variance). Untuk mengetahui perlakuan-perlakuan mana yang berbeda nyata secara statistik dilakukan pengujian dengan uji wilayah berganda Duncan (Duncan multiple range test).

\section{Prosedur Kerja}

Pembuatan chicken nugget dimulai dengan menyiapkan daging ayam petelur afkir yang segar strain Logman berumur 24 bulan. Daging ayam yang telah dibersihkan dipotong-potong kemudian dicampur dengan bumbu-bumbu yang telah disediakan tambahkan bahan-bahan seperti tepung untuk setiap perlakuan masingmasing $25 \%$ tepung sagu, tepung tapioca, tepung maizena dan tepung beras ketan, penyedap $3,75 \%$, es $20 \%$, bawang putih $3,75 \%$ serta susu bubuk $3,75 \%$ dan kuning telur $10 \%$ kemudian digiling dengan food procecor. Adonan yang telah terbentuk dikukus dengan menggunakan waterbath dengan suhu yang telah ditentukan yaitu $75^{\circ} \mathrm{C}$ selama 45 menit kemudian angkat dan dinginkan dicetak dengan menggunakan cetakan masukan dalam kocokan putih telur, diguling dalam tepung panir dan kemudian digoreng dengan menggunakan minyak goreng pada suhu $170^{\circ} \mathrm{C}$ selama 5 menit. Dilanjutkan dengan analisis laboratorium. Untuk lebih jelasnya prosedur pembuatan chicken nugget dapat dilihat pada gambar 1. 


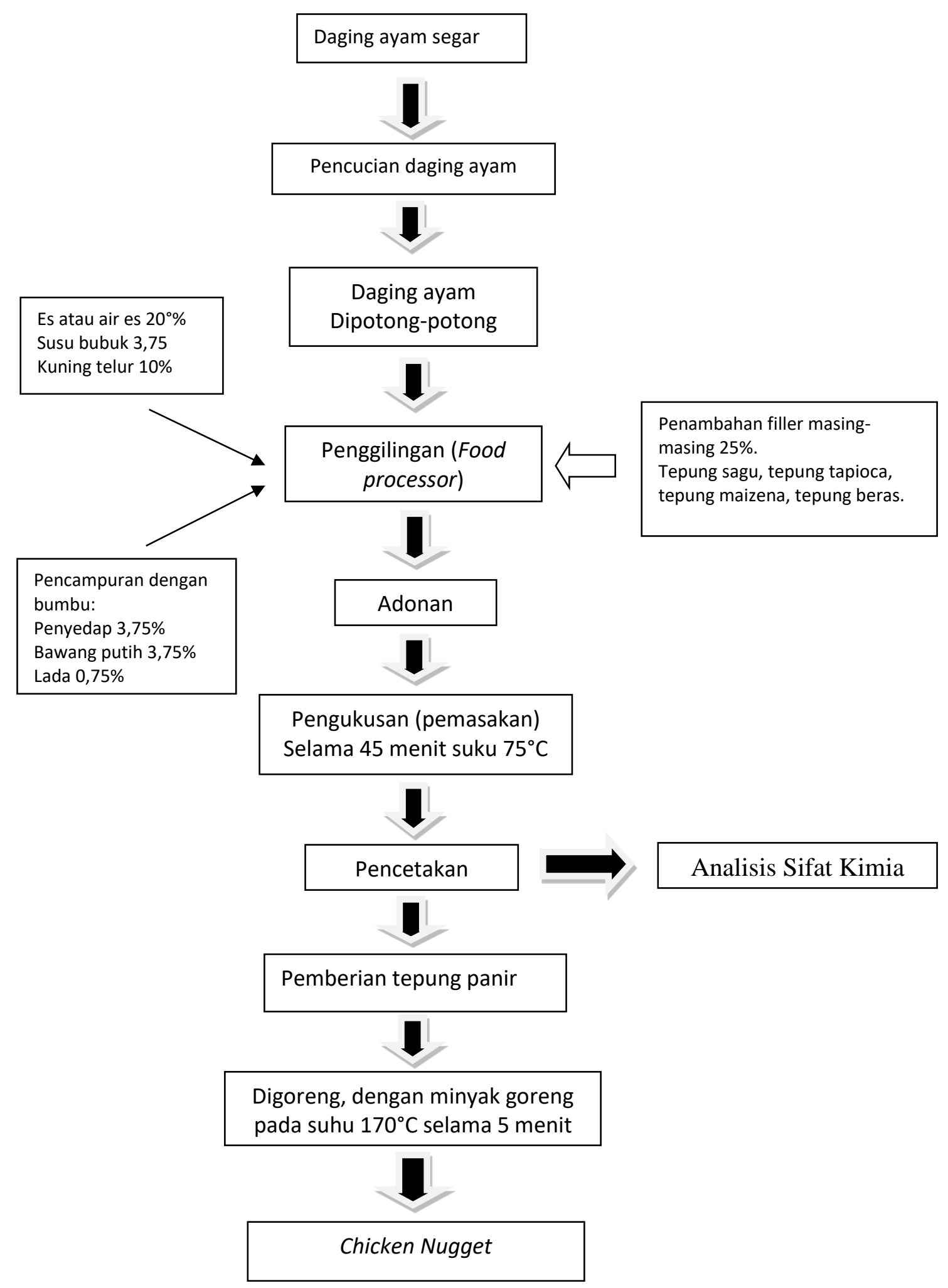

Gambar 1. Prosedur pembuatan chicken nugget 


\section{Pengukuran parameter chicken Nugget}

1. Derajat Keasaman $(\mathrm{pH})$ (Ockerman, 1983). Sampel chicken nugget seberat 25 gram ditambahkan air dstilata, 50 ml air destilata,kemudian di blender sampai homogen. Sebelum $\mathrm{pH}$ meter digunakan angka penunjuknya harusdikalibrasi dengan menggunakan $\mathrm{pH}$ netral setelah angka penunjuk pada $\mathrm{pH}$ meter stabil makaa elektroda $\mathrm{pH}$ meter dicelupkan kedalam sampel yang telah diblender dan dibaca nilai $\mathrm{pH}$ yang diperoleh.

2. Analisa Proksimat (AOAC,1984), yang terdiri dari:

a. Kadar Air. Sampel chicken Nugget seberat 3 gram dimasukkan kedalam cawan logam yang telah diketahui beratnya. Kemudian cawan berisi sampel dimasukkan kedalamoven dengan suhu $105^{\circ} \mathrm{C}$ selama 4-6 jam hingga berat cawan dansampel konstan. Setelah itu dimasukkan kedalam desikator dan ditimbang beratnya, kemudian dihitung persentase kadar air sampel. Kadar air sampel dihitung sebagai berikut:

Kadar air $(\%)=$

berat sampel awal - berat sampel akhir berat sampel awal $x 100 \%$

b. Kadar Abu. Disiapkan cawan yang sudah bersih dipanaskan dalam tanur pada suhu $400^{\circ} \mathrm{C}$ selama 1 jam, dengan tang penjepit cawan diambil dari tanur dan dinginkan didalam desikator selama 1 jam, kemudian ditimbang (a), sampel seberat 5 gram dimasukkan kedalamcawan porselin yang telah diketahui beratnya (b0 kemudian dimasukkan kedalam tanur listrik dengan temperature $400-600{ }^{\circ} \mathrm{C}$ selama 24 jam. Setelah dikeluarkan dari tanur dan dimasukkan ke dalam desikator untuk didinginkan, lalu ditimbang (c).

Kadar abu $(\%)=$

$$
\frac{c-a}{\text { berat sampel (b) }} \times 100 \%
$$

c. Kadar Lemak. Sampel chicken nugget sebanyak 5 gram dimasukkan kedalam selongsong pengekstrak, (a), labu penampung yang telah bersih dikeringkan dalam oven pengering selama semalam pada suhu $105^{\circ} \mathrm{C}$ dinginkan dalam desikator kemudian di timbang (b) dimasukkan kedalam labu soxlet dan diekstraksi dengan menggunakan Hexane diatas penangas air (watebath) selama 16 jam. Setelah selesai pelarut yang ada dalam labu pengekstrak didestilasi. Kemudian labu tersebut dipanaskan didalam oven $105^{\circ} \mathrm{C}$ selama 1 jam dan ditimbang (c). Persentase kadar lemak 
sampel dihitung dengan rumus berikut:

Kadar Lemak $(\%)=$

$\frac{\text { Berat labu akhir }(c) \text {-Berat labu awal }(b)}{\text { Berat sampel }(a)} \times$ $100 \%$

d. Kadar Protein. Seberat 0,2 gramsampel chicken nugget dimasukkan kedalam labu Kjeldahl100 ml, kemudian ditambahkan 2 gram $\mathrm{K}_{2} \mathrm{SO} 4$ dan $\mathrm{HgO}$

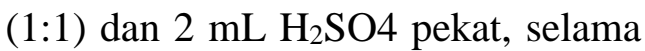
30 menit dilakukan dekstruksi sampai diperoleh cairan berwarna jernih. Setelah dibiarkan dingin tambahkan $35 \mathrm{~mL}$ air suling dan10 mL $\mathrm{NaOH}$ pekat sampai berwarna coklat kehitaman lalu dilakukan destilasi. Hasil destilasi ditampung dalam erlemeyer $125 \mathrm{~mL}$ yang berisi $5 \mathrm{~mL}$ $\mathrm{H}_{3} \mathrm{BO}_{3}$ selanjutnya dititrasi dengan HCL 0,02 $\mathrm{N}$ menggunakan indikator. Hal yang sama dilakukan untuk blanko.

Kadar nitrogen dapat dihitung berdasarkan rumus:

$\% \mathrm{~N}=$

$\frac{\text { ml titrasi (sampel-blanko)xN HClx14,007 }}{\text { Berat sampel }} x$

$100 \%$

$\%$ protein $=6,25 \times \% \mathrm{~N}$ f. Kadar Karbohidrat. Kandungan karbohidrat dihitung berdasarkan rumus sebagai berikut: Kadar karbohidrat $(\%)=100 \%-\%$ air $-\%$ lemak - $\%$ protein - $\%$ abu.

\section{HASIL DAN PEMBAHASAN}

\section{Derajat Keasaman (pH)}

Faktor penting lain yang menentukan pembuatan chicken nugget yang merupakan produk emulsi yang membutuhkan $\mathrm{pH}$ tinggi (diatas $\mathrm{pH}$ isoelektrik protein) untuk mengikat air. Pengukuran nilai $\mathrm{pH}$ chicken nugget bertujuan untuk mengetahui kualitas chicken nugget yang dihasilkan. Hasil pengukuran nilai derajat keasaman $(\mathrm{pH})$ dari keempat macam chicken nugget dengan nilai rata-rata berkisar 6,17-6,42 untuk keempat macam chicken nugget. Rataan $\mathrm{pH}$ terendah sebesar 6,17 diperoleh dari chicken nugget yang menggunakan tepung sagu (T1) sedangkan rataan $\mathrm{pH}$ tertinggi sebesar 6,42 diperoleh dari chicken nugget yang menggunakan tepung beras ketan (T4).

Nilai $\mathrm{pH}$ yang dihasilkan dalam penelitian ini masih sesuai dengan kisaran pH normal, karena menurut Ockerman (1983) daging olahan yang baik mempunyai $\mathrm{pH}$ 5,5-6,5, $\mathrm{pH}$ isolektrik daging menurut Gunardi (1986) berkisar 
Tabel 1. Rataan Pengaruh perlakuan terhadap mutu chicken nugget

\begin{tabular}{lllll}
\hline \multirow{2}{*}{ Parameter } & \multicolumn{4}{c}{ Perlakuan } \\
\cline { 2 - 5 } & $\begin{array}{c}\mathrm{T} 1 \\
(\text { Sagu })\end{array}$ & $\begin{array}{c}\text { T2 } \\
\text { (Tapioka) }\end{array}$ & $\begin{array}{c}\text { T3 } \\
(\text { Maizena) }\end{array}$ & $\begin{array}{c}\text { T4 } \\
\text { (beras ketan) }\end{array}$ \\
\hline Derajat keasaman (pH) & $6,17^{\mathrm{c}}$ & $6,25^{\mathrm{bc}}$ & $6,38^{\mathrm{ab}}$ & $6,42^{\mathrm{a}}$ \\
Kadar air (\%) & $53,00^{\mathrm{a}}$ & $51,10^{\mathrm{a}}$ & $51,86^{\mathrm{a}}$ & $52,54^{\mathrm{a}}$ \\
Kadar abu (\%) & $1,83^{\mathrm{a}}$ & $1,93^{\mathrm{a}}$ & $1,89^{\mathrm{ab}}$ & $1,95^{\mathrm{a}}$ \\
Kadar Lemak (\%) & $10,85^{\mathrm{a}}$ & $10,09^{\mathrm{ab}}$ & $10,36^{\mathrm{a}}$ & $9,20^{\mathrm{b}}$ \\
Kadar Protein (\%) & $11,22^{\mathrm{a}}$ & $9,89^{\mathrm{a}}$ & $10,22^{\mathrm{a}}$ & $10,99^{\mathrm{a}}$ \\
Kadar Karbohidrat $(\%)$ & $23,16^{\mathrm{b}}$ & $26,85^{\mathrm{a}}$ & $26,67^{\mathrm{a}}$ & $25,32^{\mathrm{ab}}$ \\
\hline
\end{tabular}

Keterangan: Superskrip berbeda pada baris dan kolom parameter yang sama berarti berbeda sangat nyata. $(\mathrm{P}<0.01)$

antara 5,2-5,4. PH yang berada di atas titik isoelektrik mengakibatkan protein dapat mengikat ion hydrogen dari air karena sifat protein adalah polar.

\section{Kadar Air}

Air merupakan komponen penting dalam bahan makanan, karena air dapat mempengaruhi tekstur, cita`rasa makanan (Person, 2003). Kadar air dalam bahan makanan ikut menentukan penerimaan dan daya tahan bahan tersebut. Sebagian besar dari perubahan-perubahan bahan makanaan terjadi dalam media air yang ditambahkan atau berasal dari bahan itu sendiri. (Fardiaz et al., 1992).

Kadar air dari empat macam chicken nugget rata-rata berkisar antara 51,8653,10\%. Ockerman (1983) menyatakan bahwa kadar air dalam daging olahan adalah 50-65\%. Dengan demikian dapat dikatakan bahwa hasil penelitian ini masih berada pada batasan kadar air dalam chicken nugget yang diinginkan, sesuai dengan standart SNI bahwa kadar air untuk chicken nugget maksimum $60 \%$ (Annonimous, 2002).

\section{Kadar Abu}

Sebagian besar bahan makanan sekitar $96 \%$ terdiri dari bahan organik dan air (Winarno, 1991). Sisanya terdiri dari unsur mineral yang dikenal sebagai zat anorganik atau kadar abu. Jumlah garam dan mineral pada penelitian ini diinterpretasikan dengan kadar abu chicken nugget.

Kadar abu dari keempat chicken nugget hasil peneltian ini rata-rata berada pada kisaran 1,83-1,95\%. Kadar abu ini dipengaruhi oleh kadar abu bahan baku nugget dan bahan lain yang ditambahkan. Kadar abu daging berhubungan erat dengan kadar protein daging serta jaringan bebas lemak. Marcos (1994) menyatakan bahwa kadar abu yang tinggi 
berarti terdapat cukup banyak senyawa kimia dalam bentuk garam yang ditambahkan untuk menstabilkan emulsi dan menambah intensitas rasa pada chicken nugget.

Berdasarkan hasil analisi keragaman ternyata perlakuan memberikan perbedaan yang tidak nyata $(\mathrm{P}>0,05)$ terhadap nilai kadar abu yang menggunakan tepung sagu (T1), tepung tapioca (T2), tepung maizena (T3) dan tepung beras ketan (T4). Dalam hal ini kadar abu dari keempat chicken nugget adalah sama.

\section{Kadar lemak}

Kadar lemak dari keempat macam chicken nugget rata-rata berada pada kisaran 9,20-10,85 \%. Kadar lemak hasil penelitian ini masih berada pada batas normal sesuai dengan Standart Nasional Indonesia maksimum untuk kadar lemak yaitu $20 \%$ pada produk akhir (Anonimous, 2002).

Menurut Kramlich (1973) lemak menyumbangkan palatabilitas yang besar pada chicken nugget. Menurut Indriani (1982) jenis dan jumlah minyak atau lemak yang ditambahkan mempengaruhi emulsi adonan nugget serta sifat-sifat kimia dan fisik dari nugget dapat diperbaiki dengan penggabungan (Comminuted) yang baik oleh jaringan lemak dan derajat emulsifikasi yang tinggi.
Berdasakan hasil analisis keragaman ternyata perlakuan memberikan perbedaan yang nyata $(\mathrm{P}<0,05)$ terhadap kadar lemak dari keempat chicken nugget. Dilanjutkan dengan uji wilayah berganda Duncan terlihat bahwa perlakuan T1 (tepung beras ketan) berbeda nyata dengan T4 (tepung sagu) tapi sama dengan T2 (tepung tapioka) sama dengan T4 (beras ketan). Dari hasil penelitian ini ternyata perlakuan (T1) mempunyai kadar lemak tinggi dan kadar lemak terenda pada perlakuan T4 namun masih jauh dari batas maksimum yang disyaratkan. Kadar lemak dalam chicken nugget selain sebagai sumber energy juga berperan dalam pembentukan emulsi daging serta menambah keempukan (Jayasena, 2013)

\section{Kadar Protein}

Kadar protein dari keempat macam chicken nugget hasil penelitian ini, memperlihatkan bahwa rata-rata kadar protein berada pada kisaran 9,89-11,22\% Rata-rata kadar protein untuk merk So Good yang ada dipasaran khususnya di supermarket berada pada batasan protein yang didinginkan. Kadar protein chicken nugget berhubungan erat dengan jumlah dan jenis daging ayam yang digunakan serta bahan pengisi filler (Mastuti, 2008)

Sifat-sifat fungsional protein adalah sifat-sifat yang menentukan perilaku protein dalam makanan selama 
pengolahan yang akan mempengaruhi mutu makanan dan penerimaanya oleh konsumen. Sifat-sifat fungsional itu menurut Fardiaz et al. (1992) meliputi sifat-sifat sensoria tau organoleptik misalnya: tekstur, citarasa, kekenyalan, kelarutan dan pengembangan. Sifat-sifat tegangan permukaan, misalnya emulsifikasi dan penyerapan.

Berdasarkan hasil analisis keragaman perlakuan memberikan perbedaan yang tidak nyata $(\mathrm{P}>0,05)$ terhadap kadar protein dari chicken nugget yang menggunakan T1 (tepung sagu), T2 (tepung tapioca) T3 (tepung maizena) dan T4 (tepung beras ketan). Hal ini diduga karena kandungan karbohidrat dan filler yang digunakan lebih tinggi mengakibatkan jumlah protein yang sama antara keempat chicken nugget.

\section{Kadar Karbohidrat}

Karbohidrat dengan fungsinya yang berganda memegang peranan penting dalam pelbagai pengolahan paangan. Karbohidrat adalah bahan yang fungsinya secara alami adalah memberikan kekuatan mekanik dan tekstur. Dalam berbagai produk baru, karbohidrat tetap dirangcang sebagai komponen yang memperkuat struktur produk pangan (Fardiaz et al., 1992).

Kadar karbohidrat untuk masingmasing perlakuan, rata-rata kadar karbohidrat berkisar antara 23,16 -26,85\%. Berdasarkan hasil analisis keragaman, perlakuan memberikan perbedaan nyata $(\mathrm{P}<0,05)$ terhadap ke empat chicken nugget yang dihasilkan. Dengan uji wilayah berganda Duncan terlihat bahwa perlakuan T2 berbeda nyata dengan T1 tetapi tidak berbeda nyata $(\mathrm{P}>0,05)$ dengan T3 dan T4. Selanjutnya T3 berbeda nyata lebih tinggi dari T1 tetapi tidak berbeda nyata dengan T1. Secara keseluruhan dapat dilihat bahwa perlakuan T2 kadar karbohidrat yang tinggi sesuai dengan sifat kimia dari tepung tapioka yang mengandung kadar karbohidrat yang tinggi sedangkan yang terendah diperoleh dariperlakuan (T1) tapi masih berada pada kisaran yang normal.

\section{KESIMPULAN}

Dari hasil penelitian ini disimpulkan bahwa bahan pengisi filler dengan menggunakan tepung tapioka (T2) dan tepung sagu (T1) menghasilkan Chicken nugget yang lebih baik dibandingkan dengan tepung maizena (T3) dan beras ketan (T4) disukung oleh sifat kimia.

\section{DAFTAR PUSTAKA}

Anonimous, 2002. Syarat Mutu Chicken Nugget (SNI 01-6683-2002). Badan Standarisasi Nasional Jakarta. 
Alam, N dan Nurhaeni. 2008. Komposisi Kimia dan Sifat Fungsional Pati Jagung Berbagai Varietas yang Diekstrak Dengan Pelarut Natrium Bikarbonat. J. Agroland 15 (2): 89 -94 .

AOAC. 1984. Official AnaMethod of Analysis. Asosiation of Official Analytical Chemist. Washington, DC.

Das, R., D.P. Pawar, and V.K. Modi. 2013. Quality characteristics of battered and fried chicken: comparasion of pressure frying and conventional frying. Journal Food Sci. Technol 50 (2): $284-292$.

Fardiaz, D., N. Andarwulan, H. Wijaya dan N.L Puspitasari.1992. Teknik Analisis Sifat Kimia dan Fungsional Komponen Pangan (Petunjuk Laboratorium). Depdikbud Dirjen Dikti. PAU Pangan dan Gizi.

Ginting, N. 2006. Penambahan bahan pengikat pada nugget itik serati. Jurnal Agribisnis Peternakan. 2 (1): 6-10.

Gumilar, J., O. Rachmawan dan W. Nurdyanti. 2011. Kualitas fisiko kimia nugget ayam yang menggunakan filler tepung suweg (Amorphophallus campanulatus B1). Jurnal Ilmu Ternak. 11 (1): 15.

Gunardi, R.E. 1986. Dasar-dasar Ilmu Teknologi Daging. Proyek Peningkatan Perguruan IPB. Bogor.

Indriani, L. 1982. Pengaruh Berbagai Jenis Minyak dan Lemak dalam
Pembuatan Sosis Ikan Tongkol. Skripsi. Fakultas Teknologi Pertanian, IPB. Bogor.

Jayasena, D.D., D.U. Ahn, K.C. Nam, and C. Jo. 2013. Flavour chemistry of chicken meat: A Review. Asian Australia. Journal Anim. Sci. 26: $732-742$

Kramlich, W.E. 1973. Sausage Product. In The Science of Meat and Meat Products. Freeman and Co.P:485.

Mastuti, R. 2008. Pengaruh suhu dan lama waktu menggoreng terhadap kualitas fisik dan kimia daging kambing restrukturisasi. Jurnal Ilmu dan Teknologi Hasil Ternak 3 (2): 23-31

Marcos, A. 1994. Mutu Kimia, Organoleptik, dan Mikrobiologi Beberapa Merek sosis Sapi komersial di Bogor. Skripsi. IPB. Bogor.

Persson, E., I. Sjokolm and K. Skog. 2003. Effect of high water-holding capacity on the formation of heterocyclic amines in fried beefburgers. Journal of Agriculture Food Chemistry. 51 (15): 44724477

Rohaya, S., N. El Husna dan K. Bariah. 2013. Penggunaan bahan pengisi terhadap mutu nugget vegetarian berbahan dasar tahu dan tempe. Jurnal Teknologi dan Industri Pertanian Indonesia. 5 (1): 7 - 16

Winarno, 1991. Kimia Pangan dan Gizi. PT Gramedia. Jakarta. 